\title{
次世代TFT作製に向けたシリコン結晶化技術
}

\author{
東 和文 ${ }^{1}$, 平松 雅人 ${ }^{1, \dagger}$ ，松村 正清 1 \\ ${ }^{1}$ (株) 液晶先端技術開発センター（テ244-0817 神奈川県横浜市戸塚区吉田町292番地）
}

\section{Crystallization Technology of Si Thin Films for Future TFTs}

\author{
Kazufumi AZUMA, ${ }^{1}$ Masato HIRAMATSU, ${ }^{1, \dagger}$ and Masakiyo MATSUMURA ${ }^{1}$ \\ ${ }^{1}$ Advanced LCD Technologies Development Center Co., Ltd., 292 Yoshida-cho, Totsuka-ku, Yokohama, Kanagawa 244-0817
}

(Received April 20, 2006)

\begin{abstract}
Thin film transistor, which had been in practical use with amorphous silicon (a-Si) as base material in 80's, blossomed into poly-Si TFTs by a driving force of the Excimer Laser re-crystallization technology. The feature of the Excimer laser fits for the lateral growth of Si thin films, i.e., its characteristics such as short wavelength, high power density, low coherency and short pulse enable the progress of the advanced "Phase Modulated Excimer Laser Annealing (PMELA)" method. We have developed a position-controlled large grain Si arrays process using the PMELA method. Excimer laser still requires many refinement to achieve the practical use of the "System displays".
\end{abstract}

Key Words: Excimer laser, Phase modulation, Si thin films, Crystallization, Thin film transistor

1.はじめに

$\mathrm{Si}$ 薄膜に高光強度のレーザー光を照射して，Siを溶融・ 再結晶化させるレーザー結晶化法は，3次元集積回路を目 指したSi積層結晶構造 (SOI) 形成技術として，1980年代か ら1990年代初頭にかけて盛んに研究されてきた. 当時は 連続発振のArイオンレーザーがその主流であったが, 残 念ながら結晶化過程を十分に制御できるには至らなかっ た.レーザー結晶化法が再び注目され始めたのは，1990 年代に本格的に登場したノート型PCの表示装置がきっか けとなっている.すなわち, 非晶質 $\mathrm{Si}$ 薄膜トランジス夕 (a-Si TFT) 駆動の液晶ディスプレイ (LCD)の応用が高精細 分野へと広がった結果, a-Si TFTに比べて桁違いに高性能 の多結晶Si TFTが要求されてきたからである。ここでは, 3次元集積回路の研究で培われたこの技術が大いにヒント になったが，同時に，この休眠期間内に長足の進歩を遂 げていたエキシマレーザーが強力な道具となった。

レーザー結晶化におけるエキシマレーザー利用の長所 をTable 1に示す．実用的なエキシマレーザーは放電によっ て生じた励起状態の希ガス原子とハロゲン原子とが作る 不安定な分子(Excited Dimer)が元のばらばらな安定状態に 戻る際の誘導放射を利用する。代表的なエキシマレー ザーには，希ガス原子とハロゲン原子の組み合わせに
よって, $\operatorname{ArF}($ 発振波長 $=193 \mathrm{~nm}), \operatorname{KrF}(248 \mathrm{~nm}), \mathrm{XeCl}$ $(308 \mathrm{~nm}), \mathrm{XeF}(351 \mathrm{~nm})$ 等がある。

これらの発振波長が短いので, レーザー光は数nm厚の $\mathrm{Si}$ 薄膜にも高効率で吸収される。また， $1 \mathrm{~J} /$ shotにも達する 超高出力エネルギーのパルス発振であるので, 大面積ガ ラス基板を高スループットで処理することが可能であ る。（現在の量産用のレーザーの仕様は $1 \mathrm{~J} / \mathrm{shot}, 300 \mathrm{~Hz}$ 程 度である。また，100 nm厚のSi膜を溶融させるには，レー ザー光の表面反射や熱エネルギーのガラス基板への拡散 を考慮しても， $1 \mathrm{~J} / \mathrm{cm}^{2}$ 程度の試料面上光強度でよい. した がって，450 mm $\times 550 \mathrm{~mm}$ の大面積ガラス基板全面を 1 回 照射するには, $10 \mathrm{~s}$ を要しない).

更にパルス幅が30 ns 程度と極短パルス幅のパルス発振 であるので, ガラス基板表面に堆積した $100 \mathrm{~nm}$ 程度の厚 さのSi薄膜を瞬間的に融点以上に昇温・溶融しても, 基板 のガラスの温度上昇は極く僅かにとどまるという利点が ある。すなわち，ガラスからのNa等の拡散を抑えるため に， $\mathrm{Si}$ 膜とガラスの間には $1 \mu \mathrm{m}$ 程度の $\mathrm{SiO}_{2}$ 膜が挿入されて おり, 溶融 $\mathrm{Si}$ と室温のガラスとの過渡温度差 $\left(\right.$ 約 $\left.1000{ }^{\circ} \mathrm{C}\right)$ はこの $\mathrm{SiO}_{2}$ 膜の表面層 $(100 \mathrm{~nm}$ 程度)が吸収するので，ガラ ス基板に熱損傷が生じない。

通常，レーザー光は出射面において空間的な分布を 持っているので，これを試料表面で均一化する必要があ

†現在の所属 : 東芝松下ディスプレイテクノロジー(株)（テ366-0032 埼玉県深谷市幡羅町1-9-2）

${ }^{\dagger}$ Present address: Toshiba Matsushita Display Technology Co., Ltd., 1-9-2 Hatara-cho, Fukaya, Saitama 366-0032 
Table 1 Feature of a Excimer laser for Poly-Si TFT processes.

\begin{tabular}{l|l}
\hline Short wavelength & Highly efficient absorption for Si thin films. \\
\hline High power & Advantageous for large area processing. High throughput. \\
\hline Low coherency & $\begin{array}{l}\text { "Appropriate" low coherency enables homogenization using a } \\
\text { cylindrical lens array unit. }\end{array}$ \\
\hline Short pulse & $\begin{array}{l}\text { Melting /recrystallization of Si thin films without thermal damage to a } \\
\text { glass substrate. }\end{array}$ \\
\hline
\end{tabular}

る、エキシマレーザーは, 多モード発振であって，しか も光利得が極めて高いために低 $Q$ の共振器を用いることか ら, 出射光には空間的並びに時間的な干渉性が低い. こ の特徴から, Fig. 1に示すように, まず出射光を多数の細 いビームに分割して, 各細線ビームを試料の照射領域全 面に拡大すれば，各細線ビームのエネルギーを重ね合す ことができるので, 試料面上の照射領域内光強度を均一 にすることができる(このような光学素子はホモジナイ ザ1)と呼ばれており, 半導体の露光器やプロジェク夕等に も使われている).

これら特徵のために, Si膜の温度制御が比較的容易で, 溶融・再結晶化過程を制御しやすいことが，短期間にエ キシマレーザー結晶化(ELA) 技術を実用レベルにまで押し 上げた2-4) といえる.

量産に用いているELA法では, Fig. 1のようにホモジナ イザを通過後に長尺・狭幅のビームに整形して，1回照射 と, 照射幅の $1 / 20$ 程度のステップの基板の微小移動とを繰 り返すことにより，基板面に堆積されたSi膜を結晶化す る。エキシマレーザーには，パルス・パルス間のエネル ギー摇らぎが数\%以上もあるが，これが結晶化膜の物性 に及ぼす悪影響は，この多数回照射によって抑制され る.また, 多数回照射によって結晶化特性の履歴現象 (特 に初回の照射と2回の照射では物性が変化する)も抑制さ れる。このような工夫を加えることによって，実用上必 要な均一性を確保している.

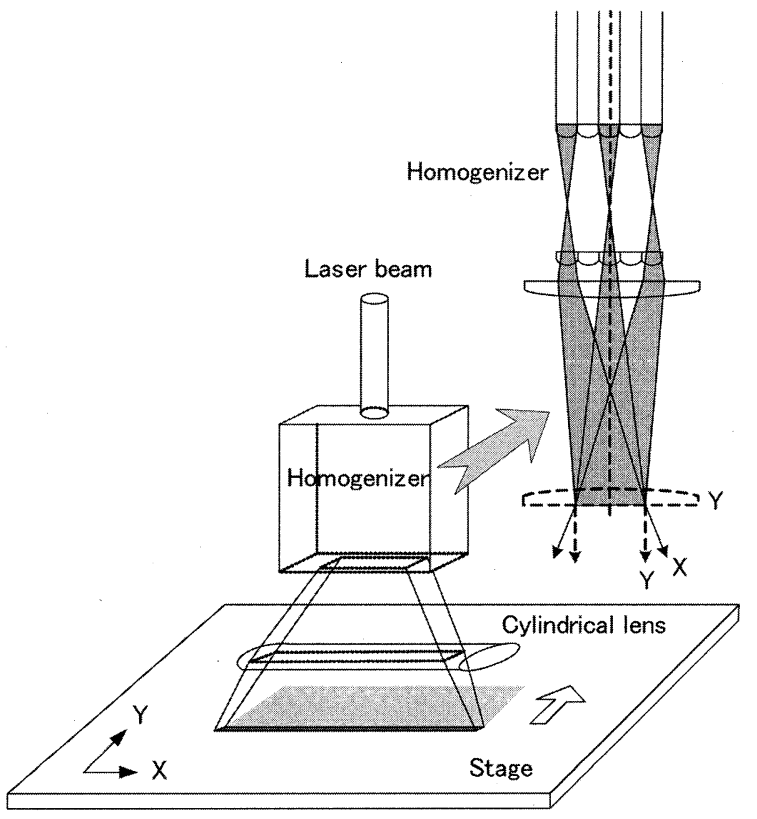

Fig. 1 Principle of a cylindrical lens array homogenizer and a beam path for the ELA.
しかしながら, 現在量産に用いられているELA法では 広い面積に均一強度のレーザー光が照射するので, 照射 領域内では，一様に溶融が生じて結晶核が高密度に発生 し，これら結晶核が照射の終了に伴って同時に成長を開 始する。結晶核同士の衝突によって結晶成長は直ちに停 止するので, 得られる結晶粒径は $100 \mathrm{~nm}$ 程度と極めて小 さい。一方, TFTの大きさは数 $\mathrm{mm}$ 程度であるから, キャ リヤ(電子或いは正孔)はTFTの電極(ソースとドレイン)間 を移動する間に数十回も結晶粒と結晶粒の境界(粒界)を横 切ることになる。キャリヤの運動が粒界で頻繁に妨げら れるために，キャリヤの移動度が低く，このことがTFTの 超高性能化の足枷となっている，超高性能TFTで構成され た各種回路・システムをガラス基板上に作製するために は， $\mathrm{Si}$ の大結晶粒化が求められている。

本稿では, 基板の所望の位置に大粒径Si結晶の形成が可 能な，高度な位置制御ELA技術を実現するための我々のア プローチについて紹介する。

\section{2. 位相変調エキシマレーザーアニール法}

レーザー溶融・再結晶化法は, 用いるレーザーが連続 発振型か, パルス発振型か, によって2分される. 連続発 振レーザーを用いた場合には，試料ステージをゆっくり と動かして，Siの完全溶融領域を移動する。結晶を横方向 に成長させることができるので，長い結晶粒を容易に作 製できる。しかし，このレーザー光は，いまのところ， 可視・赤外波長であって, 光エネルギーの利用効率が低 い. また光出力自体も低い. Si膜が長時間をかけて昇温さ れるので，基板のガラスの温度上昇にも細心の配慮が必 要である。しかも強い干渉性を持っているため, 試料面 上の光強度分布を微細に制御・調整することが難しい. それでも, 試料を高速でスキャンすることにより, 溶 融・再結晶化を連続的に生じることに成功しており，10 $\mu \mathrm{m}$ を越す長さの結晶粒を作ることができるようになって きた，実用化には，短波長化，大出力化，干渉性制御な どとともに，指定した位置に結晶粒を作る工夫が望まれ る.

エキシマレーザーは, $10^{8} \mathrm{~W}$ 程度の巨大パワーの紫外光 を放射するパルスレーザーである。このレーザーは，ス テッパ装置に使われていることからも判るように, 微細 な光強度分布を作ることが可能である．しかし従来のELA 法では, 均一な光強度分布を用いたために, 大きな結晶 粒を作ることはできなかった。我々は，エキシマレー ザー光波の位相を制御するエキシマレーザーアニール (Phase Modulated Excimer Laser Anneal: PMELA) 法によっ て試料面上に光強度分布を生じさせ，十分な長さの横方 向成長と位置制御とを両立させることに成功した ${ }^{5-12)}$.

2.1 エキシマレーザーアニールによる横方向成長 現在のELA量産技術では，Fig. 2 (a)に模式的に示すよ うに，光パルスの照射が終了して固化が始まると， $\mathrm{Si}$ の固 液界面付近に核が高密度に発生する，時間の経過に伴っ て $\mathrm{Si}$ 膜から熱が失われるので，これらの核は四方に成長し 


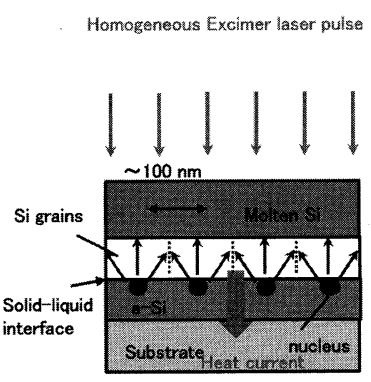

(a) Conventional ELA

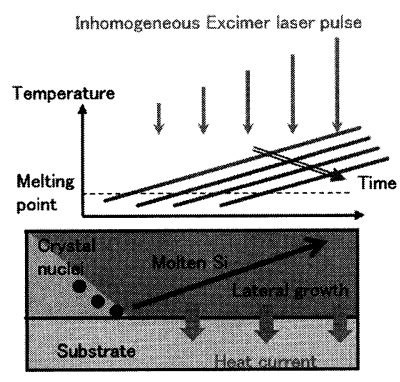

(b) PMELA
Fig. 2 Schematic diagram of a melting / recrystallization.

て結晶粒になる。結晶粒は，隣の結晶粒とすぐに衝突す るので，横方向には殆ど伸びない。この結果，その粒径 は100 nm程度と極めて小さい。

光強度を不均一にして, 核の発生領域を局在化すれ ば，結晶は横方向にも成長する．Fig. 2 (b) はその概念図 である。強度が直線的に変わる光ビームを照射すると, Si 膜には光強度分布に対応した分布で熱が蓄えられる。低 光強度の領域(図の左側)では，Si膜は部分溶融に留まる が, 高光強度の領域では，Si膜は完全に溶融して，しかも その温度が光強度と共に増す．光パルスの終了と同時 に，Si膜の蓄えた熱が基板に向けて流出するので，Si膜の 温度が下がり始める。 $\mathrm{Si}$ の部分溶融領域では，核が固液界 面付近に高密度に発生して，それらが同時に成長を始め る。結晶粒同士が頻繁に衝突するので, 従来のELA膜と同 様に，得られる粒径は小さい。一方, $\mathrm{Si}$ の完全溶融領域で は，固相領域が存在しないので，核が発生できない．Siは 融点以下まで温度が下がった過冷却の液体状態を保つ。

そして, 部分溶融領域の端で発生した核が，何者にも邪 魔されずに，この過冷却液体 $\mathrm{Si}$ 内を横方向に成長して巨大 になる。

\section{2 大結晶粒アレイの形成原理}

結晶粒の横方向成長現象を利用して大結晶粒のアレイ を形成するには，

(1)ごく狭い領域内のSi膜を部分溶融状態にして，その点 に1個だけ核を発生させること

(2)核の発生箇所を取り巻く完全溶融領域内には核の発生 箇所から直線的に上昇する温度分布を作って, 横方向成 長を継続させること

(3)試料構造を最適化して，Si膜が高温の溶融状態にある 時間を延伸すること

が必要である。(1)と（2）の仕様を兼亦備えた光強度分布 の概略をFig. 3に示す。低光強度・小面積の領域で核が発 生する。この箇所の光強度が高すぎるとSiが完全溶融する ので，核発生を制御できない。また光強度が低くすぎる と, この箇所の周辺部でも部分溶融状態が生じるから, そこで大量の核が同時発生してしまう。したがって，こ の籄所の光強度を最適值に制御する必要がある。なお, 成長領域内では，核が横方向に順調に成長していくよう に, 光強度を滑らかに増加させる。

光強度分布を微細に制御する技術は, 微細加工を目指 して開発されてきた。しかしこの露光技術は，本質的に

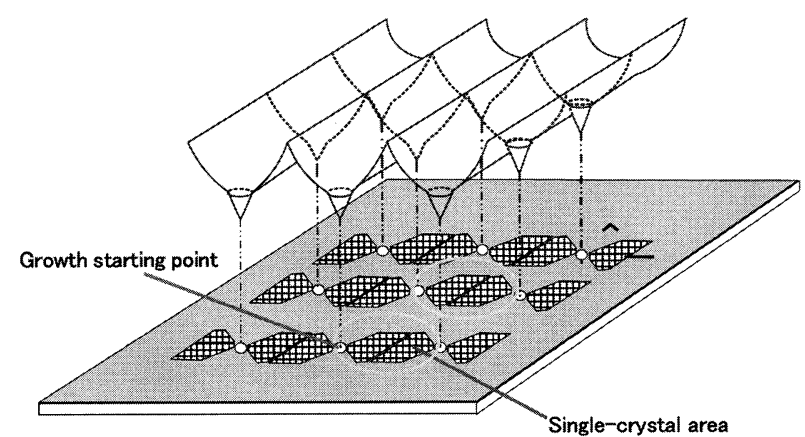

Fig. 3 Light intensity distribution suitable for large-grain crystalline arrays.

は光強度の 2 值制御技術である。一方，大結晶粒アレイの 形成には，アナログ的な光強度制御が必要である。した がってこのPMELA法に必要な位相変調素子を含む光学系 の特性は，露光装置に用いられるマスクを含む光学系の 特性とは，類似点は多いが，様々な面で異なる。

\section{3. 位相変調素子}

PMELA法は，Fig.4に示すように，近接法と投影法に大 別できる。試料のごく近傍に置いた位相変調素子が引き 起こす回折現象を用いる近接法 (Fig. 4 (a)) は，原理検証 には適するが，試料と位相変調素子との間隙を精密に制 御する必要があるという装置上の問題, 試料からの飛沫 が位相変調素子を損傷するというプロセス上の問題, な どがあって，実用性に欠ける。位相変調素子の投影像が 発生する回折現象を用いる投影法では，光学系の特性が 投影像に影響する。近接法の延長線上で考えれば，Fig. 4 (b)のように，この光学系の影響による“ボケ”がきわめて 少ない投影像を，試料から有限の間隔だけ離して，作る 方法が思い浮かぶ。これら既存の方法に対して，本研究 では，次に述べるうに，新しい方法を開発した。すな わち，光学系の影響を積極的に活用して，Fig. 4 (c) に示 すように，投影像を試料表面に結像させた。そして，投 影像の強度分布を任意に制御できる新位相変調素子と光 学系の開発に注力した.

幾何光学的に理想的な収差のない光学系を実現する技 術は既に完成している。しかしこの理想光学系でも，そ の投影像には光の波動性に原因する“ボケ”が残る。波動光 学によると，投影像の任意の一点に集まる光線は，幾何
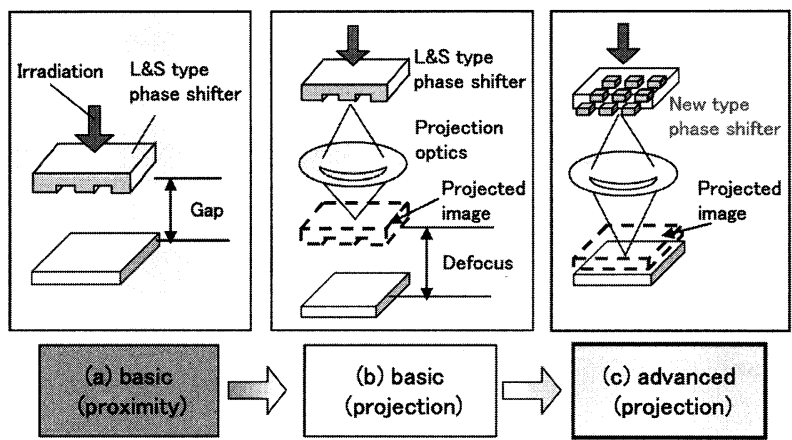

Fig. 4 Optical systems for PMELA. 
光学的な光源位置を中心とした“Airy disk”と呼ばれる円盤 状領域内に存在する源から放出された光線の総和と考元 て良い，すなわち投影像の光強度は, Airy disk内の光源の 平均值から求まる9)。な㧍, Airy diskの直径 $d$ は, たとえば $N A=0.15$ の投影光学系で $\lambda=308 \mathrm{~nm}(\mathrm{XeCl}$ レーザー光を想 定)の場合には， $d=2.5 \mu \mathrm{m}$ である.

上述の波動光学の知見を基礎にて, 単板位相変調素子 の設計法を確立した。設計例をFig. 5に示す。素子は石英 板製であって，その表面にはAiry diskの直径dに比べて小 さな間隔で多数の凹凸が作られている。石英の高い屈折 率のために，その凸領域を横切った光線には位相遅れが 生じる。逆に，凹領域を通過した光の位相は進む。素子 表面に生じた位相分布によって回折現象が生じる。大き な角度で回折した光線は小さな孔(曈：NAに相当する)を 持った投影光学系を通過できない. 回折光の一部の从が 試料に到達するので, 試料表面上の一点に扔ける光の振 幅と位相は, 位相変調素子表面の当該Airy disk内に扔ける 凹凸段差並びに凸領域と凹領域の面積割合によって変化 する。すなわち，凹領域と凸領域の占める面積割合とそ の段差を設計することにより，ほぼ任意の試料表面上光 強度分布が得られる。たとえば，Fig. 5に示した平面図の 上下方向に沿って位置を移動すると, 当該Airy disk内の状 沉はゆっくりと変化する。したがって, 光強度は二等辺 三角形状に周期的変化をして, 五の最低值は, 凹凸領域 の面積割合が最も多い付近に生じる。一方，平面図の左 右方向に沿って考えると, Airy disk内の状況は, $5 \mu \mathrm{m}$ 毎に 急激な変化をする，特にこの変化は，上下方向に沿った 光強度分布が最低になる付近で局所的に激しく変化(減少) する。

光強度分布シミュレーションの結果をFig. 6に示す。狭 い楕円状領域の光強度は周囲領域のそれの半分程度に なっており，Fig. 3に示した光強度分布が実現されてい る.

\section{4. 大結晶粒のアレイ形成技術}

レーザー結晶化では横方向成長速度が高々 $10 \mathrm{~m} / \mathrm{s}$ である から, 十分な横方向成長距離を確保するためには, 成長

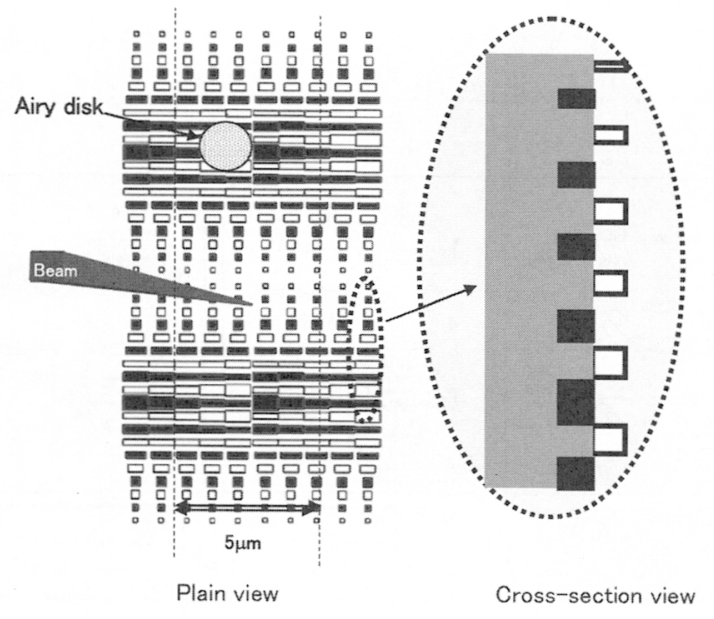

Fig. 5 Single-plate phase shifter for a large grain Si arrays.

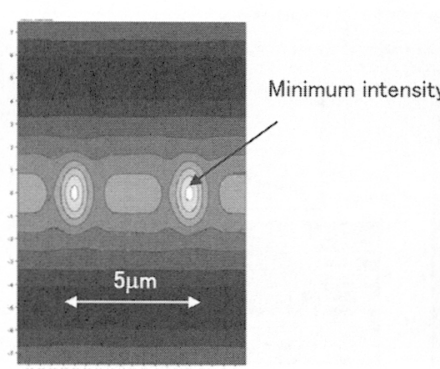

Focus position

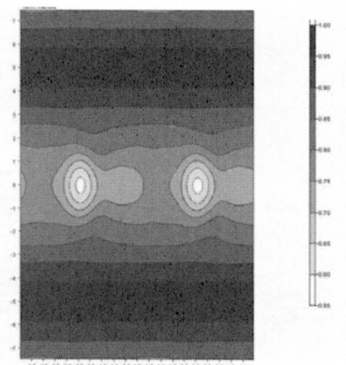

Defocused $(-10 \mu \mathrm{m})$
Fig. 6 Simulation of the light intensity distribution.

時間，すなわち $\mathrm{Si}$ 膜の溶融時間を長くしなければならな い，そのためには，(i)レーザー光照射終了直後にSi膜近 傍に蓄えられた熱エネルギーを増すこと, (ii)この熱が流 出する速度を抑えること，が重要である。主な熱流出機 構は，Si膜内を横方向に伝わる伝導流である。この抑制に はSi膜を薄くする以外にない.Si膜が蓄える熱量はその膜 厚に比例する。.Si膜の薄膜化により隇少する蓄熱容量は, Si膜の上にレーザー光を適量だけ吸収して発熱するキャッ プ層を載せることで補完できる。

Fig. 7は膜厚 $50 \mathrm{~nm}$ のS 膜にV字型光強度分布の光を照射 して得られた1次元結晶粒のSecco etching後の平面SEM像 を示す。キャップ層の蓄熱効果で, 結晶成長距離を延伸 させている. 単純な $\mathrm{SiO}_{2}$ キャップ層では蓄熱効果が不十分 であって，光吸収性のキャップ層が有効である。キャッ プ層組成の最適化で横方向成長距離を 2.5 倍以上延伸でき ることがわかった

以上のようにシリコン膜厚に最適な蓄熱層としての キャップ層の組成を決定し, 2 次元大結晶粒アレイの形成 を試みた。Fig. 8はFig. 5に示した位相変調素子を用いて5

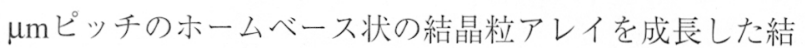
果を示す。狭い楕円状の低光強度領域では多数個の核が 発生した。この領域の両端付近で発生した二つの核はそ れぞれの前方にある完全溶融したSi内を成長した。その 際, 前方だけでなく, 両側にも広がるので, ホームベー ス状の結晶粒が対で形成されている。この対状のホーム ベース状大結晶粒の径はそれぞれ $4 \mu \mathrm{m}$ 程度であった。一 方，核発生領域内の中央付近で発生した核は，互いに衝 突しながら，それぞれの側面にある完全溶融領域内を一
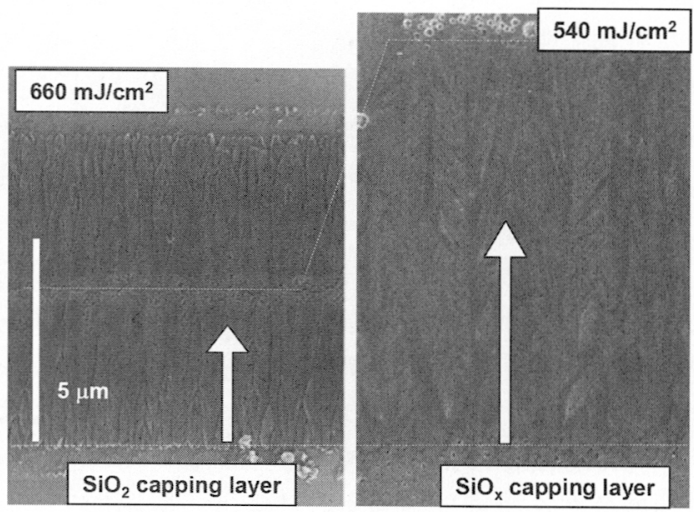

Fig. 7 Elongation of the growth length. 


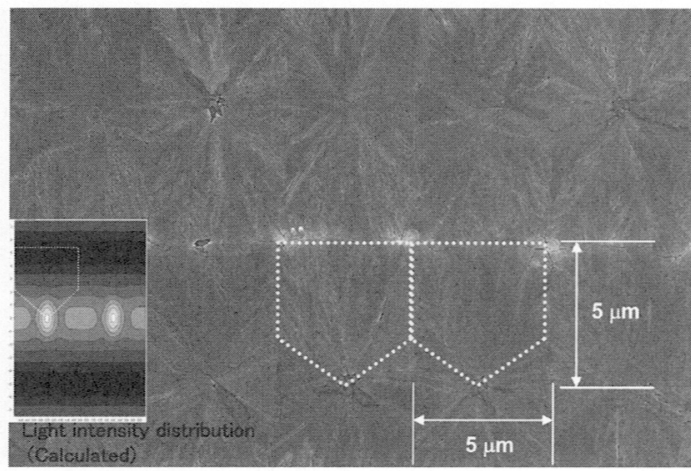

Fig. 8 SEM image of the pentagonal-shaped large grain arrays.

次元的な成長をした。このため, 大結晶粒の充填率は80 \%程度であった。結晶組織を電子線後方散乱回折パターン 法(Electron Back Scattered Diffraction Pattern: EBSP)で評価 した。EBSPのパターンから双晶の単結晶粒であると考元 た場合の単結晶領域をFig. 9に示す。ホームベース状の大 単結晶粒は $40 \%$ 程度を占めていた。残りは2〜4個の三角 形状の結晶粒より作られていた。光強度分布の窪み領域 を更に狭めることにより，単結晶粒の占める割合を高め ることができると考えている。

\section{5. まとめ}

エキシマレーザーは短波長, 高出力, 低干渉性, 短パ ルスという特長からSi薄膜の低温レーザー結晶化に最適な レーザーである。そのエキシマレーザーを用いたELA法に おいて見出された横方向成長モードは, 高度なPMELA法 の中で更に進化し，結晶成長距離の延伸だけではなく， その形状制御，粒界低減等に新しい可能性を与えてい る.

しかしながら，ここで紹介したプロセス技術以外につ いても多くの解決すべき残課題がある。すなわち，エキ シマレーザーのメンテナンス簡便化, 出力エネルギー摇 らぎの抑制，発振スペクトル狭幅化，発振周波数向上， 発振パルス幅延伸等が要望されている。光学系に関して も，偏波面制御，光学系の許容光強度の向上，光学系の 大口径化・高 $N A$ 化等が必要である。

これらの課題が解消されることで，位置を制御した大 結晶粒アレイが量産レベルで実現可能となり，TFTとして の大幅な特性改善が期待できる。さらにはLCD基板上に 高機能のTFT回路を実現することにより，ユビキタスネッ

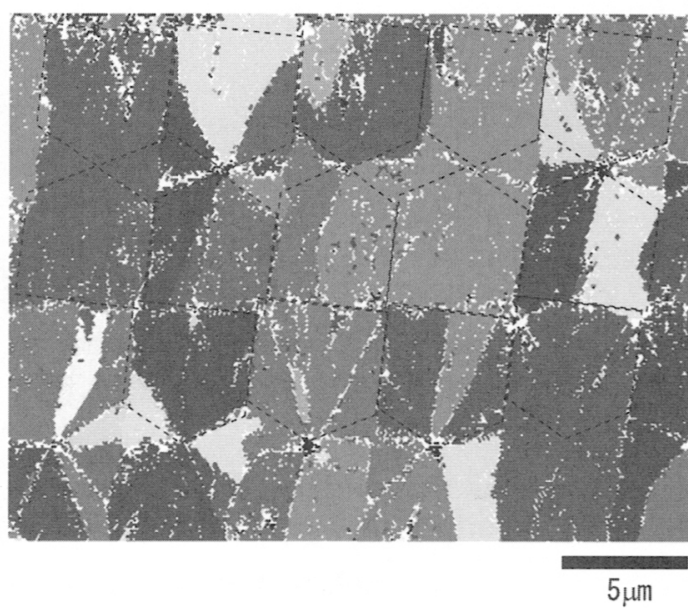

Fig. 9 Grain map of the pentagonal-shaped array by EBSP analysis.

トワーク社会の発展を益々加速してゆくものと期待され る.

\section{謝 辞}

本研究は，経済産業省の資金を基に(株) 液晶先端技術 開発センターが受託したNEDOの課題設定型産業技術開発 費助成金「エネルギー使用合理化液晶デバイス・プロセス 研究開発」に関するもので関係各位に感謝する。

\section{参考文献}

1) D. Basting and G. Marowsky (Eds. ): Excimer Laser Technology (Spinger, Göttingen, 2004) p. 130.

2) T. Sameshima and S. Usui: Mater. Res. Soc. Symp. Proc. 71 (1986) 435.

3) D-H. Choi, K. Shimizu, O. Sugiura, and M. Matsumura: Jpn. J. Appl. Phys. 31 (1992) 4545.

4) J. S. Im and R. S. Sposili: Appl. Phys. Lett. 69 (1996) 2864.

5) K. Ishikawa, M. Ozawa, C. H. Oh, and M. Matsumura: Jpn. J. Appl. Phys. 37 (1998) 731.

6) C. H. Oh and M. Matsumura: Jpn. J. Appl. Phys. 37 (1998) 5474

7) W. C. Yeh and M. Matsumura: Jpn. J. Appl. Phys. 40 (2001) 492.

8) C. H. Oh, M. Nakata, and M. Matsumura: Appl. Surf. Sci. 154-155 (2000) 105.

9) Y. Taniguchi, M. Matsumura, M. Jyumonji, H. Ogawa, and M. Hiramatsu: J. Electrochem. Soc. 153 (2006) G67.

10) T. Katou, Y. Taniguchi, M. Hiramatsu, K. Azuma, and M. Matsumura: Proc. IDW/AD '05 (Takamatsu, 2005) p. 1219.

11) M. Hiramatsu: Proc. IDW/AD '05 (Niigata, 2004) p. 325.

12) T. Katou, Y. Taniguchi, N. Akita, M. Jumonji, H. Ogawa, M. Hiramatsu, and M. Matsumura: Proc. AM-LCD 05 (Kanazawa, 2005) p. 303.
位相変調エキシマレーザーアニール

(phase-modulated excimer laser annealing)

特定の強度分布を持ったエキシマレーザー光を非晶質 $\mathrm{Si}$ である出発薄膜に照射して薄膜内に所望の温度分布を形 成する。その結果として，溶融再結晶化に伴う結晶核発 生と溶融 $\mathrm{Si}$ 内の結晶成長とを制御し，二次元位置制御した 大結晶粒を形成する。従来のエキシマレーザーアニール 技術では，空間的に均一な光強度のエキシマレーザー光
照射と数十 $\mathrm{mm}$ のステージ移動を繰り返して, 試料全面に わたって比較的粒径の揃った均一な多結晶(結晶粒径：〜 $0.1 \mathrm{~mm}$ 程度) Si 薄膜を作る。一方, PMELAでは最適化され た光強度分布を有するエキシマレーザー光を1，2回照射 することによって，数mm径の位置制御したSi大結晶粒を 照射領域に一括形成する。 